\title{
MONEDA Y TERRITORIO: LA REALIDAD Y SU IMAGEN
}

\author{
POR

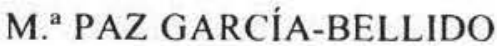 \\ CEH, CSIC. Madrid*
}

\section{RESUMEN}

Se valora la utilidad de la Numismática, con ejemplos documentales, en la delimitación geográfica de ciertos tipos de territorio: étnicos, políticos, económicos, sociales o religiosos. Tambien se discute el valor que la moneda jugó en la Antigüedad como imagen de una ciudad o un territorio, trayendo a colación la del jinete ibérico y las monedas sicilianas Hispanorum.

\section{SUMMARY}

I tray to show that Numismatic can be a very useful document on territorial delimitation studies: ethnic, political, economic, social and religious. It also played in the Antiquity an important role in the image that a political city or ethnic territory acquired voluntary or involuntary, for example the «jinete ibérico» and the Sicilian coins Hispanorum.

El convencimiento de los historiadores del siglo pasado de que la moneda era un documento básico para la reconstrucción de muchas facetas de nuestras antiguas ciudades, había atraído a este campo a especialistas en varias materias ajenas al estudio de numerario, animando a su vez a los numísmatas a buscar fuera de su demasiado restringida especialidad las razones históricas que provocaron el fenómeno de la acuñación. Nombres de tan variadas especialidades como Th. Mommsen, A. Alföldi, L. Breglia, L. Müller, L. Robert, K. Kraay, M. Gómez Moreno o J. Zobel, son dignos de mención por sus aportaciones. Después, los estudios han discurrido

- Este trabajo fue leido en el congreso internacional La peninsula ibérica en la Antigüedad: imagen de un territorio, celebrado en Toledo, mayo de 1993. Agradezco a los organizadores - Domingo Plácido y Javier Sánchez-Palencia- el que me permitan publicarlo aquí. en general por vias más especializadas y con objetivos tan parciales que han hecho perder a unos y otros el interés por la colaboración y a la vez la perspectiva de lo que en realidad buscaban, comprender la moneda en su historia y aprovechar la moneda para la Historia. Hoy, el movimiento pendular parece dirigirse de nuevo hacia su antiguo rumbo, aprovechando el evidente desarrollo metodológico de ciertas parcelas de la numismática, como la metrología, la tipologia y la circulación monetaria, para objetivos de interés histórico más general, pero la verdad es que, así como esas parcelas numismáticas han gozado de un excelente desarrollo, estudios teóricos o de síntesis no han sido frecuentes, por lo que para un tema como «moneda y territorio» cuento con pocos soportes sólidos sobre los que trabajar, y mi contribución va a ser más un planteamiento de posibilidades, con sus ejemplos, que una aportación teórica, cuya sintesis pudiera presentarse como definitiva. Es evidente que la moneda hispánica no se ha empleado todavía como documento fundamental para los trabajos de delimitación territorial, ni para los estudios sobre la imagen de un territorio, pero es indudable que puede jugar un papel muy importante en ambos casos.

La moneda es un objeto arqueológico más a la hora de ayudar a la delimitación del territorio de una ciudad o de un estado bien sea éste político, comercial o religioso, y de verificar las transformaciones que ese territorio sufre en su extensión durante una época. La información que nos proporciona a través de su dispersión y procedencias es semejante a la de cualquier otro objeto arqueológico poseyendo sin embargo dos considerables ventajas: el hecho de que lleve escrito su topónimo y el de que sus emisiones sean consecutivas, con cronologías rela- 
tivas, $y$ en muchos casos absolutas, muy precisas, proporcionando una información continua y datable. Pero la moneda es además un documento oficial, el emblema elegido por las elites ciudadanas como representación de la comunidad, por ello la interpretación de sus tipos puede dar valiosa información sobre la imagen que el estado quiere proyectar de sí mismo, o la que el resto de las comunidades politicas, ajenas a esa ciudad, adquieren de ella a través de su imagen monetal. Para la imagen que proyecta ese territorio al exterior es la moneda un objeto importante, cuya riqueza informativa depende naturalmente de la variedad de cecas y de iconos de la zona en estudio. Son mucho más explícitos por ejemplo, los trabajos posibles en este aspecto con el numerario griego que con el romano, y más con el hispánico que con el galo.

Los testimonios aqui elegidos, desprovistos de su ropaje teórico, sirven para dos tipos de estudio: I, la realidad: delimitación de un territorio geográfico -étnico, político, económico, social o religioso- en los que la moneda actúa como un documento arqueológico más, testigo hoy de una cultura material de ayer; y II, su imagen: fenómenos ideológicos en los que la imagen monetal de una ciudad o de un territorio, muchas veces copia iconográfica de otros iconos ajenos sin contenido propio en sus inicios, es recargada de una nueva iconologia y transformada en el emblema de una comunidad, tanto por los propios ciudadanos como por gentes ajenas a ellos, auténtica bandera étnica, fomentando un espiritu nacionalista de homologación de los ciudadanos y de éstos con la comunidad. La continuidad del documento numismático permite seguir su evolución, a través de hitos precisos, de ese desarrollo siempre lento y longevo, de las ideologías nacionales. ${ }^{\prime}$

\section{TERRITORIO Y REALIDAD}

\section{Territorio étnico}

No entraré aquí a comentar los problemas que plantea la delimitación de los territorios étnicos a través de su cultura material. Los procesos continuos de copia y aculturación ocurren en niveles tan profundos que en muchísimas ocasiones se han bo-

\footnotetext{
' Los documentos que voy a presentar en este resumen han sido tratados por mi en otros lugares con otros objetivos pero, como es lógico, tanto las discusiones bibliográficas como los paralelos documentales están allí ya planteados y me parece mejor obviarlos ahora en lo posible. Naturalmente las referencias van a pie de página para quienes estén interesados en una argumentación más detallada.
}

rrado las huellas de la entidad cultural propia. Los restos lingüisticos vienen en ayuda de esta falta de documentación material clara, permitiendo delimitar ciertos territorios étnicos a través de los topónimos, antropónimos, etc. En el caso de Hispania, la riquísima documentación monetal con los topónimos escritos en ella ha proporcionado información segura, por su extensión en el espacio y homogeneidad en las formas y en el tiempo, para delimitar territorios culturales de los que las fuentes no nos habian dado suficientes datos. Uno de los más claros hoy es el de iberos y celtiberos, y uno de los más versátiles es el de la situación de gentes púnicas en el territorio bético (fig. 1), que según las fuentes deberíamos adscribir sólo a las costas mediterráneas donde se hallarian las grandes colonias de Abdera, Sexi, Málaca y Gades y los libiofenicios citados por los historiadores ${ }^{2}$. En las fuentes se omite empero cualquier enclave púnico al interior cuyos territorios han sido sin embargo localizados hace tiempo gracias a sus monedas: Abla, Ituci, Urso, Vesci, Olontigi, etc. y ahora Turriregina, Arsa y Tagilit ${ }^{3}$. Pero no sólo los topónimos, sino un estudio de la iconografia monetal, ha llevado a identificar como púnicos los iconos de Obulco, Ulia, Carmo e Ilipa, o los de Bailo y Salacia ${ }^{4}$.

Todas estas características externas de las monedas púnicas, entre las que es primordial la epigrafía, permiten formar cuatro grupos diferentes: $a$ ) el

\footnotetext{
${ }^{2}$ Recientemente he defendido, con argumentos numismáticos, la diferencia cultural entre vacceos y celtiberos: "Los ámbitos de uso y la función de la moneda en Hispania», III Congreso histórico-arqueológico hispano-italiano, Toledo, septiembre 1993, en prensa. Respecto a los "libyfoinikes" de nuestras fuentes deben responder en griego a una formación gramatical similar a la de «syrofoinikes» de Lucano y Juvenal, refiriéndose unos a los cartagineses y otros a los fenicios del este, forma semejante a la utilizada para nombres étnicos compuestos como "Keltiberes", los celtas de Iberia, según H. M. Hoenigswald, "Celtiberi: a noten, Celtic Language, Celtic Culture 1990, pp. 13-14. Debo esta referencia a J. de Hoz.

${ }^{3}$ B. Mora, «Las cecas de Malaca, Sexs, Abdera y las acuñaciones púnicas en la ulterio baetica" en Numismática Hispanopúnica, VII Jornadas de Arqueologia fenicio-puinica, Ibiza 1993, pp. 63-96, M. P. Garcia-Bellido, «Las cecas libiofenicias", I lbm. pp. 97-147; ead. "Sobre las dos supuestas ciudades béticas Ilamadas Arsa", Anas 4-5, 1991-1992, pp. 81-92; ead. "Célticos y púnicos en la Beturia según sus documentos monetales», en Celtas y túrdulos: la Beturia, Cuadernos Emeritenses 9, Museo Nacional de Arte Romano, Merida 1995, pp. 257-291. Para una recopilación y comentario de los epigrafes fenicio-púnicos en Hispania $c f$. C. Alfaro, «Epigrafia monetal púnica y neo-púnica en Hispaniam, Glaux 7, Milán 1991, pp.109-154; para Tagilit ead. "Una nueva ciudad púnica en Hispania, TGLYT -res publica Tagilitana, Tijola (Almeria)", AEspA 1993, pp. 229-243.

${ }^{4} C f$. comentario en M. P. García-Bellido, «Las religiones orientales en la península ibérica: documentos numismáticos», $A E s p A$ 1991 , pp. $37-81$.
} 


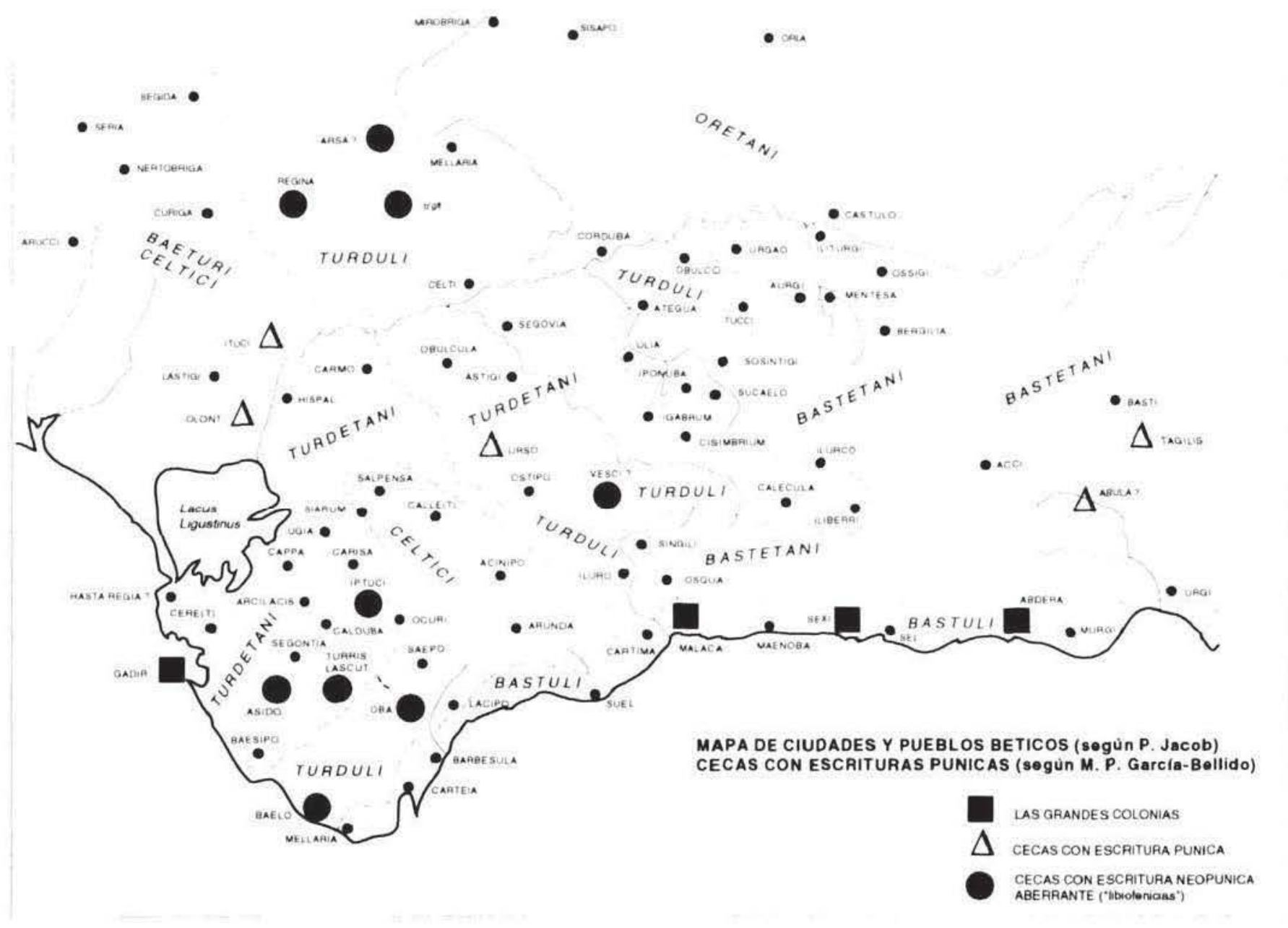

Figura I

de las colonias más antiguas con un letrero fenicio o púnico normalizado como Gades, Malaca. Abdera y Sexi; $b$ ) el de las otras ciudades no citadas por las fuentes como púnicas pero cuya epigrafia púnica normalizada las detecta como tales - Tagilit, Ituci. Olontigi, Urso(?); y c) aquéllas cuyos letreros están escritos en un neopúnico aberrante, denominadas desde Zobel como libiofenices y formando un grupo compacto alrededor de Gades y otro en la Beturia túrdula. Su cultura está en pleno proceso de trasformación gráfica lo que provoca una falta de normativa que dificulta sobremanera la lectura de sus epigrafes: Asido, Oba, Bailo, Lascuta, Iptuci y ¿Vesci? en la trascosta gaditana, y Turrirecina más Arsa en la Beturia túrdula donde encontramos sus monedas y son citadas por las fuentes; $d$ ) podrian sumarse otras cecas cuya iconografia es claramente púnica y sus conexiones con el lenguaje utilizado en las estelas cartaginesas de los siglos $\|11-\| 1$ a.C. es intimo, haciéndome pensar que, aunque su leyenda sea latina, su población de elite hubo de contar con púni$\cos$. Este es el caso de Carmo, cuya arqueologia ha puesto de manifiesto una larga perduración púnica

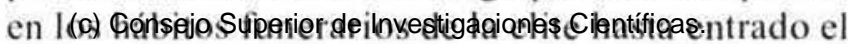
Licencia Creative Commons Attribution (CC-by) España 3.0
Imperio, o de llipa y Obulco ${ }^{2}$. Con estas premisas consultemos el mapa y veremos que las cecas púnicas se integran en los territorios adscritos por las fuentes a los túrdulos, o se acercan a ellos. Es cierto que en la literatura los limites de estas gentes no son claros ni homogéneos, pero la distribución hecha por Jacob sobre el mapa de Tovar hace sospechar que la nomenclatura de túrdulos en Mela, Estrabón y Plinio sea una referencia a turdetanos semitizados ${ }^{\circ}$. La imagen del territorio ocupado por feniciopúnicos en la Bética es pues, según la numismática, mucho más extensa, dispersa y compleja de lo que

M. Bendala, "Los cartagineses en Espana, en Historia Gie neral de Expaña y América vol. 1-3, Madrid 1987. pp. 115-168. esp. 148 y 166-168. Cf. también mi articulo cit. n. 3. pp. 55-60.

Más aclaraciones sobre este tema en mi capitulo "Las monedas libiofenicias", cit. (n.3), pp. 129-131. En el mismo sentido, con aportaciones filológicas, J de Hoz. "Tartesio, fenicio y céltico veinticinco años despuésw. Tartessos veinticinco años después: 1968 a 1993. Jerez de la Frontera, en prensa. El mapa de mi fig. I procede de P. Jacob, «L róle de la ville dans la formation des peuples ibéres». $\mathrm{MCV}$ 1985, pp. 34-35. Sobre él he señalado, con simbolos mayores, los enclaves fenicio-punicos, añadiendo además los de ltuci. Olontigi, Tagilit, y en la Beturia los de http:/laespa. revistas, csiąs/lindex.php/aespa 


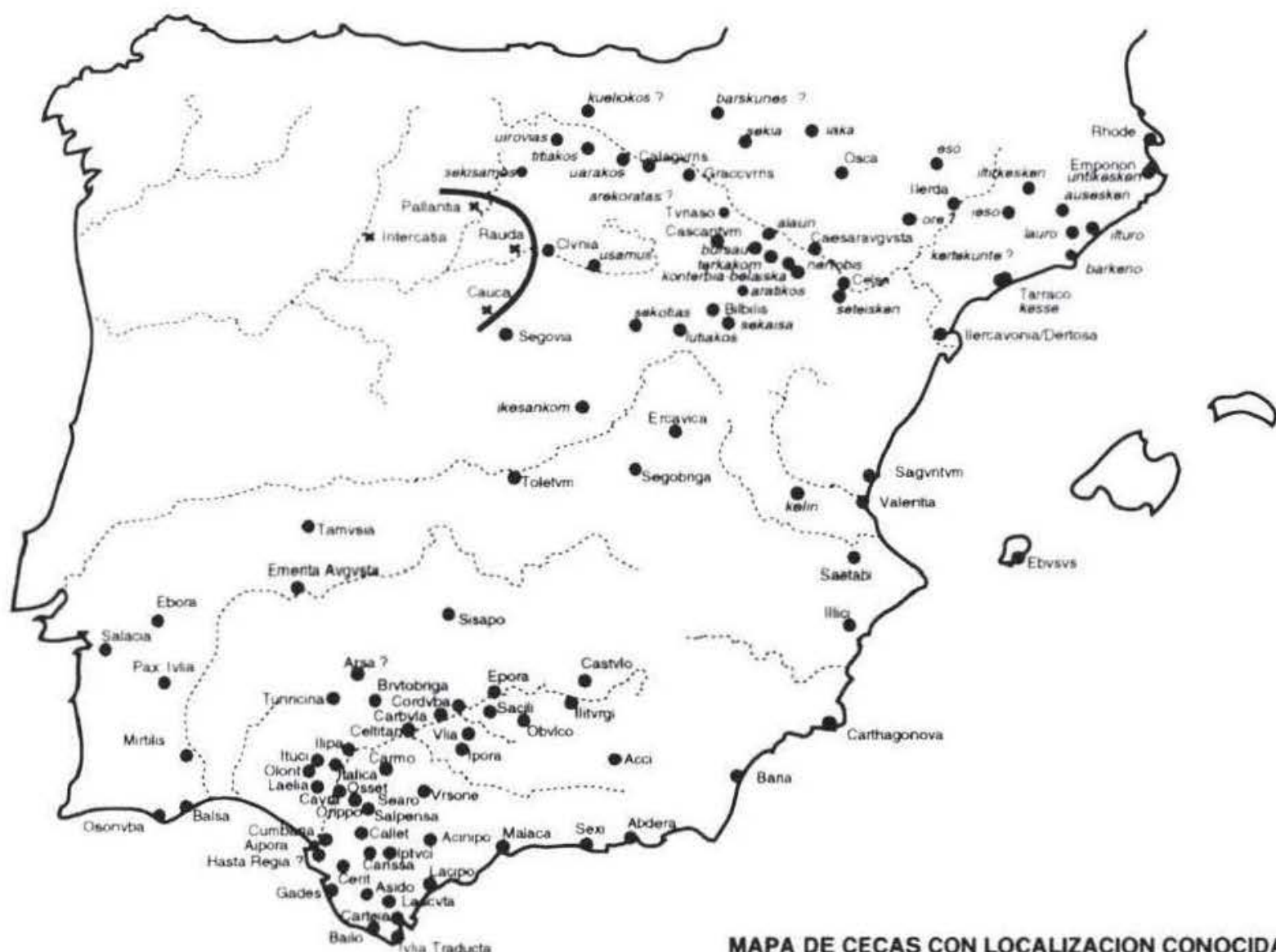

Figura 2

MAPA DE CECAS CON LOCALIZACION CONOCIDA

Dentro de linea curva, las ciudades vacceas que nunca tuvieron ceca.

Por motwos de nitidez, no incluimos los diacriticos en las transcripciones bericas

las fuentes literarias a primera vista parecian trasmitir: más aún, es posible que a juzgar por la escritura y la iconografia monetales algunos de sus grupos urbanos hayan venido de Africa en el siglo III dada la sorprendente similitud de su lenguaje iconográfico con las estelas cartaginesas de esas mismas fechas, mercenarios quizás venidos con los bárquidas y asentados aqui desde entonces, para los que el pago pudo consistir precisamente en esas tierras, en muchos casos ya habitadas de antiguo?

Territorios étnicamente más compactos son los delimitados por las acuñaciones de la Hispania citerior. El desciframiento de la escritura ibérica por Gómez Moreno, efectuado básicamente sobre los letreros monetales, puso a disposición de los estudios lingüísticos el riquisimo repertorio de más de cien topónimos de las numerosas cecas hispanas (fig. 2). Tanto el propio Gómez Moreno, como Caro

Tierras y ciudades en muchos casos ya habitadas con cuya población estas gentes se mezclaban. Cf infra el caso de Morgantia e Hispanorum. Mela, Chorog. III,3.8
Baroja y luego Tovar conformaron un mapa étnico según los componentes lingüisticos de los topónimos, deslindando nitidamente una zona indocuropea que coincidia grosso modo con la que en las fuentes literarias se adjudicaba a los celtiberos, vacceos. vettones, etc.. de otra no indoeuropea que corria por el levante y sur peninsular ${ }^{*}$. Respecto a la porción céltica, los topónimos de las numerosas cecas del valle del Ebro ayudaron gráficamente a marcar los limites orientales, los más dificiles, entre celtiberos e iberos, precisamente en este valle donde ni la cultura material ni la información literaria eran por si solas determinantes, viniendo a ayudar eficazmente los bronces de Botorrita. Pero esta adjudicación de un territorio étnico a los celtiberos trajo sorpresas de las que no enunciaré sino dos: sekia (Egea de los Caballeros, Zaragoza) y bilhilis (Valdeherrera y el Cerro de la Bámbola). La primera ceca se halla en territorio vascón a pesar de que su topónimo parece

" Cf. la historiografia en J. Untermann, Monumenta Linguarum Mispanicarum. I, Wiesbaden 1974, pp. 45-51. 
claramente indoeuropeo, apoyando quisas la teoria defendida por Fatas de una expansion tardia en epoca ya romana de los vascones hacia el sur sobre territorio suessetano, del que sekia seria un topómimo testigo". De Bilbilis sabemos que es una ciudad celtibérica por su cultura, por su posición geografica y posiblemente por su lengua. pero por su upónimo deberiamos adjudicarla a pueblos no indoeuropeos ${ }^{i 9}$. ¿Como se explica ese islote lingüistico? i. Se trata de una ocupacion anterior de aiberos" en esa zona de la que ha quedado el testigo de este toponimo? o ¿un asentamiento de elite ibérica dentro del territorio celtiberico en relación con el mineral del Moncayo que sabemos por Plinio -34,144- y Marcial 4.55.11-cra capitalizado por la propia Bilbilis? Son todas ellas preguntas sin respuesta

Las fuentes literarias y la lingüistica precisan ademas que, de estos territorios relativamente homogéneos, habian salido gentes para buscar asentamiento en zonas que ctmicamente no les correspondian. Uno de los casos mas conocidos en llispania es el de la Beturia céltica descrita por Plinio -3.1314- y que, como él denuncia, posee topónimos celticos que difieren de los otros de la Betica. Además. la propia Lusitania habia recibido población acélti(a), emparentada con los celtiberos, todavia en época romana (Estrabón 3.1.6 y 3.3.3). Hasta ahora, solo los topónimos definian con seguridad alli asentamientos célticos, amén de cierta cultura material mesetena presente en algunos castros y necrópolis. Hoy existen datos contundentes del asentamiento en esas tierras de Celtici y C'eltiberi gracias a las monedas de la ciudad de taniusia (Villasviejas del Tamuja, (aceres) que, por tipologia, epigrafia, metrologia y factura claramente celtibéricas, buscábamos hasta ayer en la Meseta Norte (fig. 3). El hallazgo mayoritario de sus raras monedas -único resto histórico que poseemos de la ciudad-en Villasviejas, castro bañado por el arroyo de igual nombre que la ciudad antigua, Tamuja, ha venido con toda claridad a darnos testimonio de las claras descripciones de Plinio y Estrabón respecto a los Celrici y a los Celriberi de la Beturia y Lusitania, y de su intima relación con los celtiberos de la Meseta "I. Las monedas nos vienen a precisar más, se trataria posiblemente de un asentamiento tardio, no muy anterior a mediados del siglo $\|$ dado que emite con patrón y tipologia exactos a la serie de Secaisa con dos delfi-

G. Fatas, "Notas sobre el territorio vascón en la Fdad Antigua. Actas del II coloquio sobre lenguas v culturas paleo-hispanicas. Veleia 3, 1987. pp. 386-396; Untermann MLII, cit. n. anterior. A. 43 .

iii Untermann, cit (n, 8), $\wedge .73 \mathrm{~g}$.

(c) Consejo Superior de Investigaciones Científicas.

Licencia Creative Commons Attribution (CC-by) España 3.0
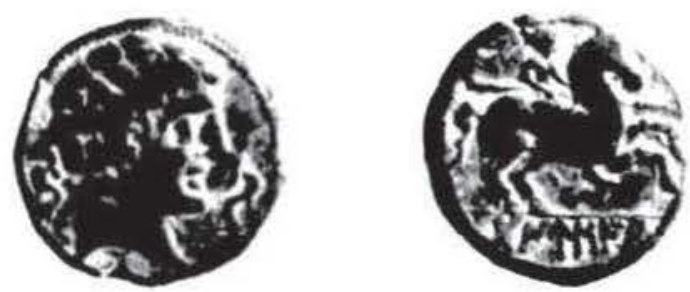

figara 3 As de ramusa (of IVD)

nes (Vives 65.6) fechables en el tránsito de los siglos ${ }^{2}$. Tema posiblemente también resuelto es dónde se encontraba la ceca de las emisiones latinas TAMVSIENS, cuya rareza dificultaba localizar el taller. pero los escasos datos de procedencias apunlan hacia la misma cona. quizas al mismo enclave tammivia TAMVSIENS Tamuja"

Un último caso presentaré como ejemplo de la ayuda que la numismatica puede prestar a la delimitación etnica de un territorio. Se trata de la ciudad de Segobriga, la Segobris republicana denominada por las fuentes como celtiberica. Aunque su localización ha estado de siempre inmersa en la controversia por la frecuencia de toponimos con el término seg-. desde los años cuarenta se identificó con la Segóbriga de Cabeza de Griego (Cuenca), a pesar de que su presencia alli en época republicana dislocaba los datos arqueológicos y literarios que para entonces poseemos de Carpetania y Celtiberia ${ }^{14}$. Pero

11 J. L. Sanches Abal \& S. Garcia Jimenes. el a eeca de Tanustas tetas del I Congrese Penmsular de $11^{*}$ tntigua, Santiago 1988. pp 153-158: mas datos y comentarios, con nuevas monedas procedentes de la cona, en C. Blìques, "tamuśla y sekaisa Nuevas monedas celtibericas en lixircmaduran, en este mismo valumen de AExp.A. Respecto a la diferenciacion entre Ciffici y Colriberi a través de los testimonios numismáticos of. M. P. GarciaBellido. cat (n, 3), aC elticos y punicos...n. pp. 283-284.

A jusgar por los datos arqueológicos de Extremadura se deben alzar las cronologias de las monedas con dos delfines de Secaisa, of L. Berrocal y A Canto, "Aproximación al estuduo de la numismática prerromana del suroeste peninsular: el ejemplo del castro de Capoten. Gaceta Numismática 97-98. 1990, pp. 67-77

Para la nueva lectura taniusia y no tanuśa cf. Garcia-Bellido. "Célficos y punicos...", cit. (n. 3), pp. 268-271. Delgado consignaba que las tres unicas piezas latinas conocidas procedian, dos de la coleceión Alvarez formada en Extremadura y Granada. y la otra de Gago de Sevilla. Hoy, una más procedente del mismo yacimiento de Villasviejas viene a apoyar la sospecha. Es muy posible pués que todas ellas se hallaran en la misma zona en que aparecen las de escritura celtiberica, of ademas el articulo de C. Blázquez en este mismo volumen. Existe una tésera todavia inédita de Villasviejas del Tamuja, que conorco gracias a una fotografia del Sr. J. Pellicer, que apoyaria esta localización si resultase ser autentica

if Cf discusión mas pormenorizada en mi articulo "Tesorillo salmantino de denarios ibericos". Zephyrus 1974, pp. 379-395: ead. "De nuevo sobre la localizacion de Segobris", Homenaje al http://aespa.revistas.csic.es/index.php/aespa 


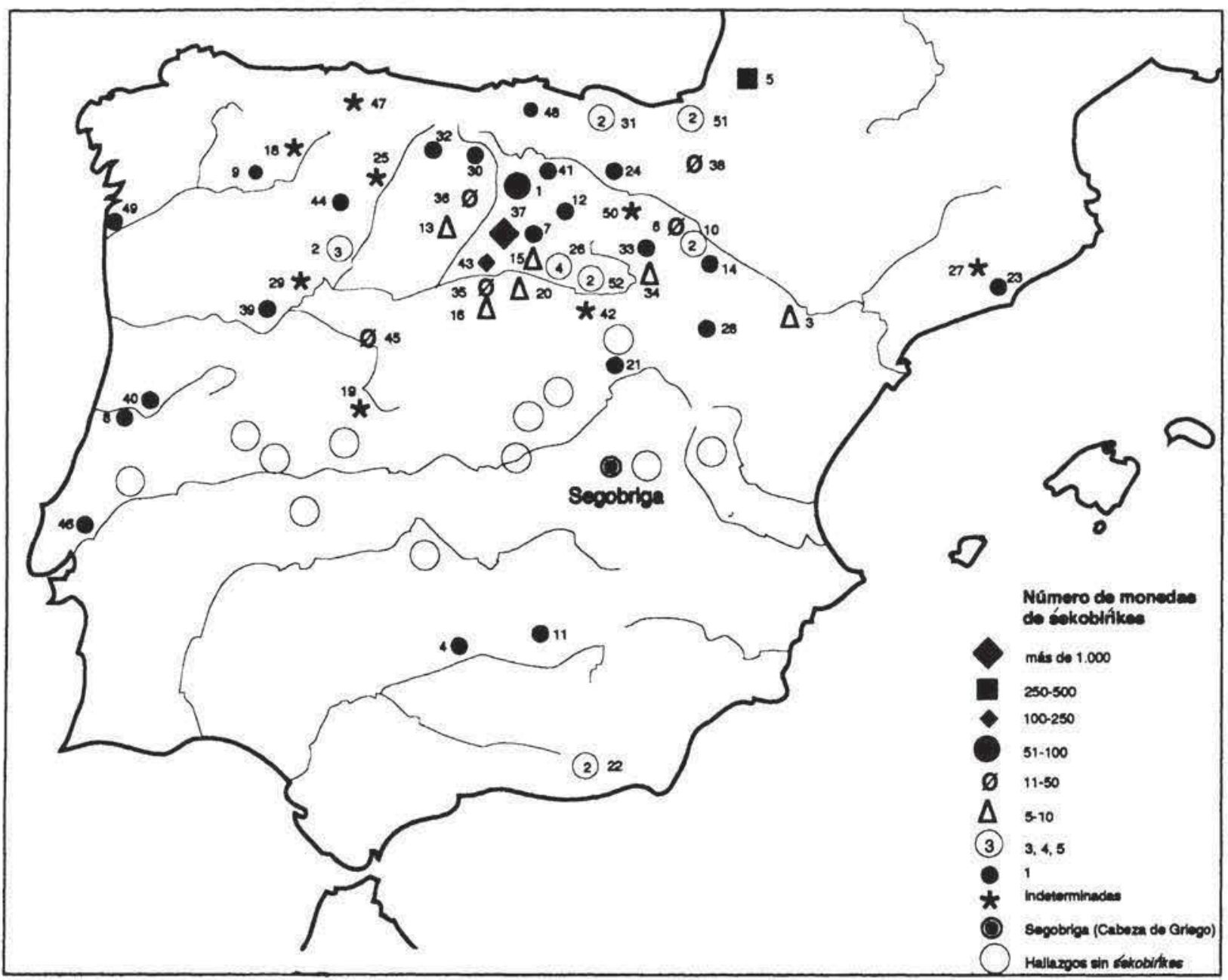

Figura 4.-Mapa de los hallazgos de moneda de śekobirikes.

es muy probable que la Segobris republicana se hallara en la Meseta norte, entre el Duero y el Pisuerga, alli donde se concentran sus monedas republicanas (fig. 4). Una expansión de los celtíberos hacia Carpetania, posiblemente dirigida por los romanos, explicaría el yacimiento de Segóbriga imperial en Cabeza de Griego sin restos importantes de fase anterior, y la frecuente aclaración en las lápidas funerarias de esta ciudad de que quienes allí yacen son Celtiberi, explicación inútil si se hallaran en su propio territorio. Estos nombres étnicos no son frecuentes en las inscripciones a no ser en aquellos casos en que el individuo se halla lejos de su patria. Lo constatan con frecuencia los soldados hispanos que van a morir al limes germánico o aquéllos otros que lo hacen en zonas limitrofes de su territorio, donde la mezcla con otras poblaciones diluye indudablemente la esencia étnica de sus individuos: Cantaber cons-

Dr. J. Maluquer, en prensa desde 1986; $c f$. una nueva versión en "Las monedas de Segobris y el yacimiento de Clunia" en AEspA 1994, pp. 245-259. tatado en Alava, Navarra y fuera de la Península; Celtiber en Galicia, Asturias y zonas marginales de Celtiberia, y Vetto, usado como cognomen en zonas colindantes del territorio vetton ${ }^{15}$.

\section{Territorio político}

La moneda no puede colaborar a la delimitación del territorio político de una ciudad, su chora, pero sí a la del territorio ocupado por ella o dominado allende sus fronteras. Aunque parezca anómalo, la moneda da más luz para determinar estos últimos tipos de territorio que para aislar aquél. El valor intrínseco que toda moneda antigua posee provoca su

${ }^{15}$ Cf. recopilación en M. C. González Rodriguez, Las unidades organizativas indigenas del área indoeuropea de Hispania. Vitoria 1986, p. 31. Esta misma argumentación en M. Almagro y A. Lorrio, «La expansión céltica en la peninsula ibérica: una aproximación cartográfica", I Symposium sobre los celtiberos. Zaragoza 1987. p. 110. Existen sin embargo excepciones como la acumulación del étnico vadiniense en el territorio que supuestamente le corresponde. 
circulación incluso fuera de su territorio; ello, más el hecho de que las ciudades sin ceca usen la moneda de las ciudades cercanas, no nos permite delimitar con detalle el territorio propio de una ciudad por su circulación monetal, aunque en principio podamos decir que el lugar donde esa moneda se concentra, el epicentro de su circulación, debe corresponder a la ciudad acuñadora, pero las ondas de dispersión no delimitan un territorio al ser afectadas por un sin fin de incidencias económicas que nada tienen que ver con las políticas. Sin embargo, los condicionantes fiscales que la política de Catón impuso en las dos provincias hispanas obligaron a un distinto tipo de moneda, plata y bronce en la $\mathrm{ci}$ terior, solo bronce en la ulterior. Fue posiblemente la recolección del impuesto en plata, cuando los pretores no desearan en especie, lo que aconsejó a ciertas ciudades de la citerior a acuñar plata para su pago $^{16}$. Burillo ha querido ver en estas ciudades las cabezas de un territorio jerarquizado, donde el resto de los núcleos urbanos no acuñarían moneda o sólo emitirian bronce, planteamiento general que puede muy bien ser cierto y de enorme valor histórico ${ }^{17}$.

Pero, son las situaciones de ocupación temporal de un territorio las más fácilmente rastreables a través de las monedas. Un excelente ejemplo es el que ofrecen las monedas hispanas de bronce en los campamentos del limes germánico en el tránsito de eras. No sabemos con seguridad cuándo es el traslado de cada una de las legiones desde Hispania a Germania, ni dónde llegan exactamente, por lo que se ha hecho un tanteo pensando que en Germania los grandes desplazamientos de las legiones tienen lugar a raiz de las grandes derrotas. Dos horizontes se utilizan para los primeros traslados: el posterior a la clades Lolliana c. -15 y el posterior a la derrota de Varus c. +9. Tras la primera, la preocupación imperial de una posible destrucción de todo lo conseguido hasta entonces en esa frontera, conllevó una acumulación de legiones traídas desde muy diferentes puntos del imperio, entre ellos Hispania, y asentadas en diversos campamentos de Germania. En algunos casos

\footnotetext{
${ }^{16}$ Teoria ya expuesta, con datos numismáticos muy concretos que la justificaban, por Amorós y Gómez Moreno que ha sido ahora planteada como hipótesis por J. R. Richardson, Hispaniae, Cambridge 1986, pp. 121-123. Cf. un apoyo a las teorías de Amorós y Gómez Moreno en M. P. García-Bellido, "Origen y la función del denario ibérico", en F. Heidermanns \& H. Rix (edit.), Sprachen und Schriften des antiken Mittelmeerraums. Festschrift für J. Untermann, Insbruck 1993, pp. 97-123.

17 F. Burillo, «Sobre la situación de las ciudades celtibéricas de Bilbilis y Segeda", Kalathos 3-4, 1983198-4 pp. 287-309; id, "Sobre el territorio de los lusones, belos y titos en el siglo "I a.C.n, Estudios de Homenaje al Dr. A. Beltrán, Zaragoza 1986, pp. $529-549$.
}

éstos fueron de vida muy corta quedando por tanto poco rastro arqueológico para identificar las tropas alli asentadas pues no han aparecido, ni es de esperar que aparezcan, sellos legionarios que las denominen. Los más tempranos y con cronologias más precisas (fig.5) son los que partiendo de Vetera I ( ${ }^{\circ}$ 3 ) se fundan en el curso del Lippe: Oberaden $\left(n^{\circ} 6\right)$, con vida desde el -11 hasta el $-9 / 8$, y su sucesor Haltern $\left(n^{\circ} 4\right)$ desde el -8 hasta el +9 en que tras la derrota de Varus es también abandonado. La presencia de sigillata y de moneda de Roma y Nemausus en esas latitudes es ya indicio claro de territorio castrense, puesto que una y otras son objetos importados y traídos sólo para abastecer a una población inmigrada con necesidades ya adquiridas y bien desarrolladas en una zona que todavía no conoce esa cultura material romana, permitiendo determinar, sólo con su presencia, un territorio castrense. A esta moneda traída de fuera se une la céltica acuñada en la zona y que penetra en el campamento a través de las canabae que muy tempranamente se asientan en su derredor, moneda que sin embargo nunca llega a superar en abundancia la de Nemausus o Roma. Pero, así como de la aretina no podemos decir sino que procede de Italia y las monedas de Roma o Nemausus son tan mayoritarias que deben llegar por muy diferentes vias, entre ellas el propio aerarium Saturni, las otras monedas minoritarias dan una información preciosa sobre la relación entre sus lugares de origen y las tropas alli asentadas. En Oberaden el numerario recogido en excavación consta de 328 monedas repartidas de la siguiente forma ${ }^{18}$ :

$\begin{array}{lrllll}\text { Nemausus } & 302 & \text { Roma } & 3 & \text { Narbona } & 1 \\ \text { moneda céltica } & 9 & \text { Vienna } & 3 & \text { Arausio } & 1 \\ \text { Hispania(Ebro) } & 8 & \text { Copia Lugdunum } & 1 & & \end{array}$

Es indudable, como hace años propusó Giard, que la moneda de Nemausus jugó un papel claramente estatal y, en el caso que comentamos, su altísima presencia indica que las tropas asentadas en Oberaden fueron pagadas por Roma con este tipo de moneda, ella constituye el $\mathbf{9 2} \%$ del numerario del campamento ${ }^{19}$. De entre las minorías, la mone-

18 J. S. Kuhlborn \& S. Schnurbein (Hrsg), Das Romerlager in Oberaden III. BAW 27, Münster 1992, esp. Ilisch «Die Münzen aus den Ausgrabungen im Römerlager Oberaden», pp. 175-202. Más detalles en mi articulo "Moneda y campamentos militares» en Pueblos y culturas en la frontera del imperio romano, Gijón, julio 1995, en prensa.

19 Ilisch cita los porcentages de moneda de Lugdunum en otros campamentos más tardios donde la moneda de Nemausus se ve ya compensada con un numerario circulante: Haltern el $4,7 \%$, Novaesium el $7,4 \%$, pero en Dangstetten, también campamento muy temprano, tiene un $68 \%$ de presencia. 


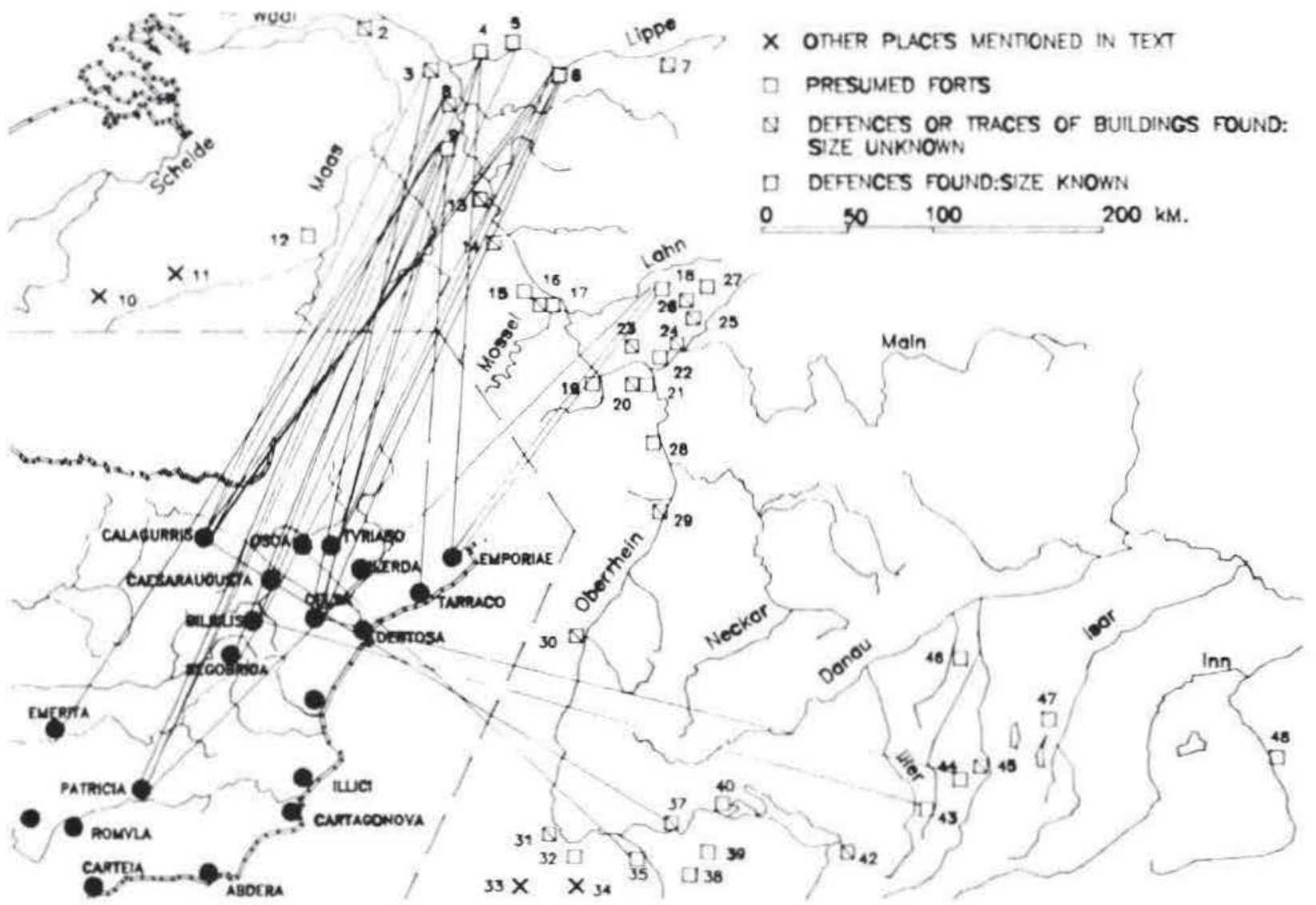

Figura 5. Hallazgos de moneda hispana augústea en los campamentos germanicos, sobre un mapa de H. Schönberger

da céltica, circulante en el territorio germano, es lógicamente la más abundante, y sin embargo de Roma sólo hay tres piezas, indicando, no sólo que ningun pago de tropa se hizo con ese numerario, sino que ninguna legión asentada en Oberaden vino directamente de Italia. Sin embargo la alta presencia de moneda de Hispania indica. en un territorio sin circulación monetal previa y muy lejano a la peninsula ibérica, que parte de la tropa alli asentada procedia directamente de Hispania y los soldados traian en el bolsillo numerario de alli. Por las tempranas fechas de la vida del campamento, del -11 al -8 , sólo pudo ser la Legio I Augusta o una vexillatio de ella, cuyo rastro perdiamos en España en el - 19 y no recuperábamos hasta el +14 en que se la menciona de nuevo ya en el Rhin. La moneda ha venido en este caso, no sólo a delimitar un territorio politico de ocupación, sino a sugerir la posible procedencia de sus habitantes ${ }^{20}$.

to Estos datos proceden de un trabajo mio en curso sobre "La moneda hispana en el limes germanico,, elaborado gracias a una ayuda de la Deutsche Forschungsgemeinschaft y del CSIC, que me permitio pasar dos meses en Alemania, y a la cordial acogida

\section{Territorio económico}

El territorio más apropiado para ser delimitado con la ayuda de las monedas es quizás el económico. Tres diferentes fenómenos monetales pueden detectar un espacio económico unitario: a) la "falsificación", tanto en los tipos como en el patrón metrológico, de la moneda fuerte del mercado por ciudades que se incoporan a él. h) la ucopian de esa moneda fuerte tan sólo en su aspecto tipológico, mientras que la metrologia se mantiene propia, lo que implica que esas ciudades tienen a su vez otros circuitos económicos importantes: y c) una circulación monetal que testimonia abundante moneda ajena en puntos fijos, permitiendo

del Dr. V. Zedelius, entonces director del gabinete numismático del Museo de Bonn a cuya memoria hoy ofrezco el trabajo, y de la Profa. Dra. M. Alföldy, Drs. H. Schubert. H. Noeske. J. Gorecki, K. Stribrny y D. Wigg del Seminario de $\mathrm{H}^{2}$ de Grecia y Roma de la Universidad de Frankfurt/M: todos ellos me facilitaron el trabajo en sus centros y me proporcionaron materiales inéditos. reciban desde aqui mi agradecimiento. En la figura 5 la cartografia del limes germanico está tomada de H. Schönberger, «The Roman frontier in Germany: an archaeological surveyn. JRS 1969, p. 150 . 
delimitar grandes espacios undos por intereses económicos comunes. Veamos, aunque sea someramente. los Ires casos.

Para el primero tenemos un ejemplo expresivo en Ampurias, cuyas monedas iniciales copian servilmente en tipo y metrologia las massaliotas Ilamadas de Auriol (fig. 6), indicando que en la primera mitad del siglo i el mercado rodo emporitano dependia claramente del circuito massaliota ${ }^{21}$. Otra "falsificacion" similar se producira siglos más tarde con la copia por los galos, asentados en el territorio que desde los Pirineos llega hasta el Loira, de la moneda rhodo-emporitana (fig. 7), y los iberos de la trascosta catalana 2 . Todos ellos. aunque en dis-

Mientras que furtwangler las ealifice de hispanas, P P Ripolle, y M Campo dudan de su adscripcion a fbera. if M P Garcia-Bellido, al as relactones ceonomicas emere Massalsa, 1 mporson y Ciades a traves de la monedan, Coloyuto sobre griegen

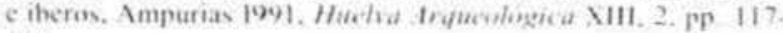
150

Tratade mas extensamente ilm.

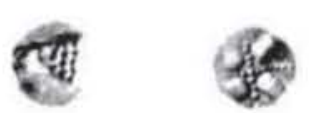

Figura fo Moncila de ag tipo suriel posiblemente acunad. sn flispanta (ol IVD)

tintos momentos, han accionado los mismos hilos ante las mismas situaciones indicando que la total dependencia economica de unos sectores respecto al centro capitalisador del circuito comercial. puede provocar una necesidad de integracion total, incluyendo la homogeneidad de la moneda. Hoy, incluso tenemos documentos escritos que constatan la veracidad de ese mercado entre los griegos e ibe. ros del Languedoc con Ampurias en el plomo de Pech-Maho (Languedoc) ${ }^{2 !}$.

M I ejeune \& J Poullows, wine transation commercial

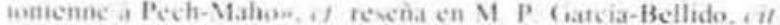
(n 211.pp 122 y 134-125, whit of I plome de Pech- Yaho... Ictu

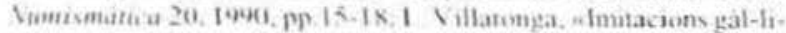
ques de les dracmes de Rhedei Imporionetem 1986. pp 21-51

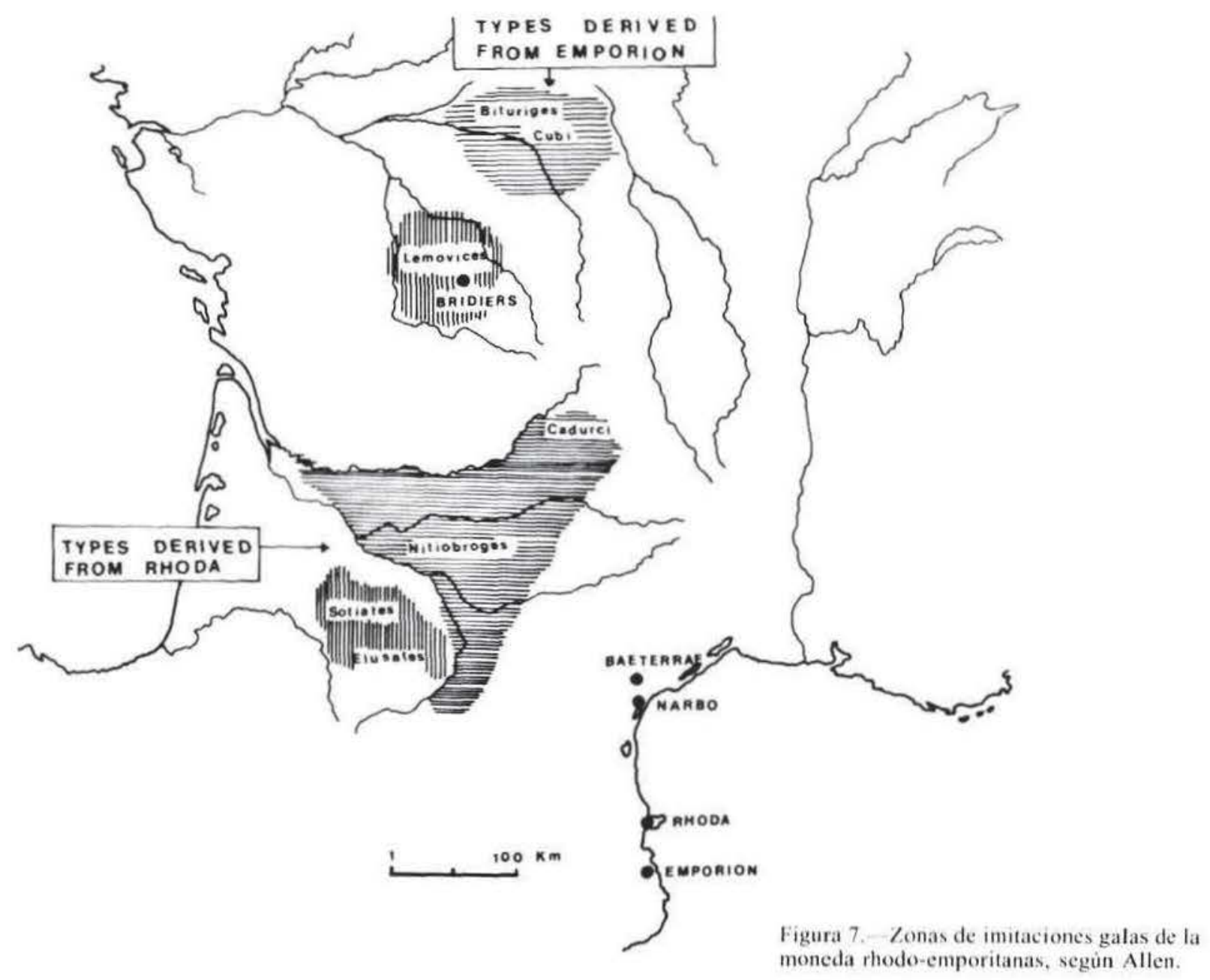


Para ciemplificar el segundo caso sería demasiado largo describir aqui cómo la copia de los tipos monetales de ciertas ciudades. en determinadas circunstancias historicas, constituye un claro indicio de la entrada en contacto con el mercado de la ceca modelo. Una ves más podemos ilustrarlo de manera breve con las monedas emporitanas que. tras la afalsificacion" de la moneda massaliota, pasan a copiar los tipos de Magna Girecia - aunque también de la Grecia propia y Jonia centros de distribución de la cerámica ática hacia occidente, para, en un siguiente paso, imitar directamente el tipo de la moneda ateniense cuya gestión económica directa podria estar llevando Atenas, seguin Sanmarti, en estos momentos en el lejano occidente con el fin de conseguir grano tras los desastres politicos en Sicilia y Magna Grecia y la ruptura de mercado. La imitacion de la moneda ateniense por Emporion es masiva. $y$ su uniformidad en tipo y valor viene a sustituir toda la enorme variación anterior, presentándose como una importante constatación del comercio directo y tijo con Atenas que E. Sanmarti habia ya sugerido para explicar otras cuestiones arqueologicas ${ }^{24}$. Este contacto e imitación provoca. o coincide con una consolidación de la conciencia politica emporitana que. por primera ves y en imitacion de la ATH de Atenas, estampa su toponimo en las monedas, EM. declarando una voluntad de exportacion de imagen que hasta ahora Emporion no habia mostrado". Mas tarde podremos decir que Emporion pasa a integrarse en el mercado púnico, posiblemente siciliano y gaditano, por la copia de los tipos monetales de caballo parado, emblema en los siglos IV - III de las ciudades cartaginesas (fig. 8): giro económico que se ve refrendado, una vez más, por las ánforas de Andalucia occidental que se encuentran en la
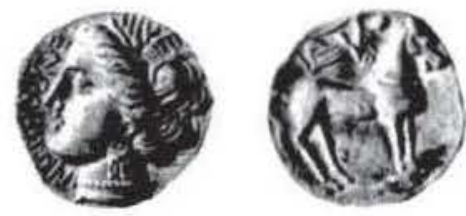

$$
\text { 11111|111111111 }
$$

Figura 8. Mencda de ag. de 1 mperion. (ol. IVDJ.

\footnotetext{
${ }^{2}$ E. Sanmarti, «Nuevos datos sobre Emporion" en F. Chaves (edit.), Griegos en occidente, Sevilla 1992, pp. 178-188; id. aMassalia et Emporion: une origine commune. deux destins différents, Marseille grecque et la Gaule. Etudes Massaliètes 3. Marsella 1992, pp. 28 y 35.39.

23 Interpretación que ya expuse en Ampurias, cit. (n. 21) y veo que coincide con la de E. Sanmarti, "Nuevos datos .... cit. (n. anterior) p. 180.
}

propia Ampurias. Es entonces, cuando Emporion ha llegado a un desarrollo politico-económico capa/ de ser epicentro del territorio comercial creado a su derredor. galos e iberos, donde provoca el atesoramiento y la servil imitación de sus propias monedas ${ }^{2}$.

El tercer tipo de territorio economico lo proporcionan los estudios de circulación monetaria. Un precioso ejemplo es el publicado por M. Campo con los hallazgos de las monedas de F busus (fig. 9) daindonos de manera grafica el circuito del comercio maritimo en el que Ebusus era una escala importante. recipendiaria y distribuidora de productos itálicos hacia Hispania, e hispánicos hacia Italia ${ }^{37}$. La moneda ebusitana, valores minimos de cobre, no puede interpretarse como moneda comercial, pero si es una espléndida muestra de movimiento de gentes, comerciantes que arriban a puertos y pagan pequeños servicios o devuelven cambio con la moneda que han recibido en la última escala. Muy interesante a este respecto me parece tambièn el que en Ebusus no haya aparecido moneda masaliota. según los datos de M. Campo, cuando en Massalia se ha encontrado numerosa cbusitana. El dato podria justificar unos viajes siempre en sentido EbususMassalia, en cuyo puerto los comerciantes del barco dejan moneda ebusitana y no al contrario pues. dada la abundancia de moneda massaliota. habrian quedado de ella testimonios en Ebusus. Otro dato importante es la concentración de piezas en Contestania y su casi ausencia en la costa sur peninsular. Es evidente, como ya suponiamos, que la redistribución de la cerámica ática. campaniense y otros objetos de lujo hacia las ricas zonas del alto Guadalquivir, hubo de hacerse por el interior a través de enclaves contestanos, donde a su vez se cargarian productos o especies, posiblemente metaliferos y agrarios, del interior. La moneda de Ebusus es aqui un claro documento de delimitación del circuito costero de un territorio comercial.

\section{Territorio socio-económico}

Cierto tipo de explotaciones económicas conlleva una marginación territorial de grupos sociales,

\footnotetext{
* Esta interpretación económica con más detalle en $\mathrm{M}$. P. Garcia-Bellido. op. cit.. (n. 21)

" M. Campo, "Las monedas de Ebusus", en VII Jornadas de Arqueologia fenicio-punica. Ibiza 1993, pp. 147-169, su fig. I reproducida por mi aqui en fig. 9. Los datos de moneda forànea hallada en Ibiza en ead, "Las relaciones de Ebusus con el exterior a través de los hallazgos monetarios (siglos III-1 a.C. m, Att! 1 Congreso Internazionale di Studi Fenici e Punici. Roma 1983. pp. 145-156.
} 


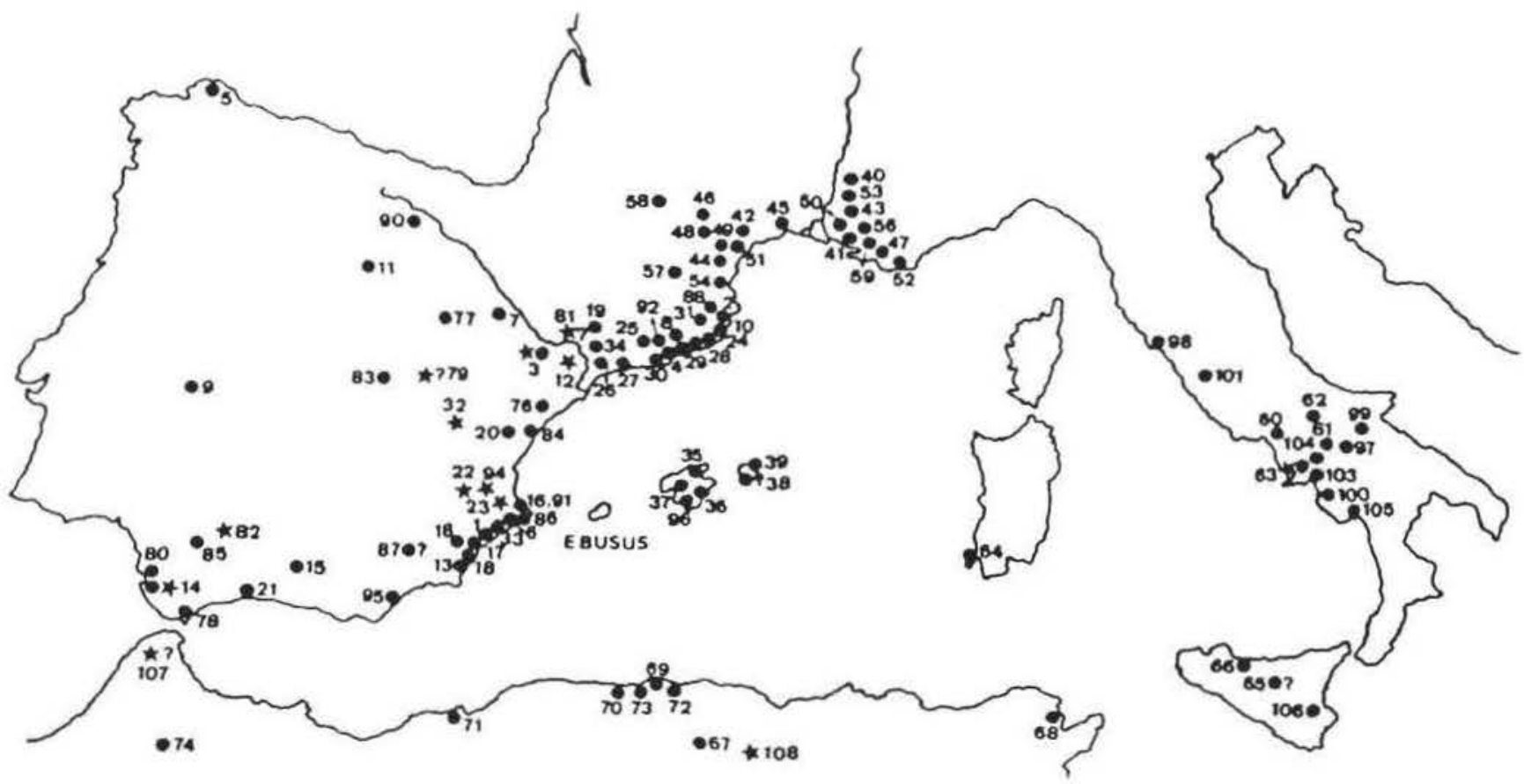

- hallazgos sueltos

* TESOROS

7 LOCALIZACION IMPRECISA

Figura 9. Mapa de halla/gos de la moneda cbusitana, segü M. Campo.

alejándolos de tal manera del resto de la poblacion que acaban constituyendo auténticos ghetos.

Núcleos homogéneos de producción conformando un territorio económico y religioso diferenciado. tenemos en zonas de explotacion mineras y agrarias a juzgar, además de por variados materiales arqueológicos, por las téseras y las monedas acunadas in situ. las contramareadas o las que poseen una tipologia especifica (fig. $\left.10 a, b \mathrm{y}^{2}\right)^{2 h}$. En Hispania es el valle del Guadalquivir, sembrado por un rosario de explotaciones de este tipo, el que ha dado el más

M. P. Ciarcia-Bellido. Ias monedas de (astulo con eserima indigena. Barcelona 1982. pp. 147-165, cal "Nuevos documentos sobre mineria y agricultura romanasm. tEsp 1986 variado y expresivo repertorio de estos materiales. Como premisa inicial conviene señalar que estos núcleos de población alejados de un sistema socioeconomico urbano y productores especializados ellos mismos, carecen precisamente de los resortes de trueque normales en sociedades de estas épocas. Estos mineros no producen sino mineral y no poseen nada con que efectuar un intercambio. Solo la moneda o un sucedaneo les posibilita adquirir aquellos bienes o gozar de aquellos servicios que unas "canabae» mineras podian ofrecerles; de ello tenemos testimonios en las Leyes de Vipasca y en las tablillas de Alhurnus maior, donde la valoración está fijada en moneda. Para ellos, como para los soldados en un campamento, es más imprescindible la posesión de un numerario que para la población urbana; por ello

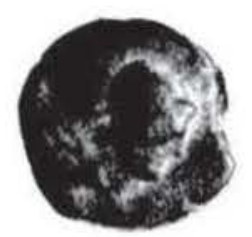

$a$

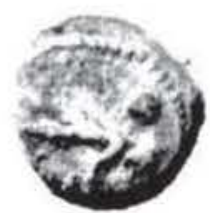

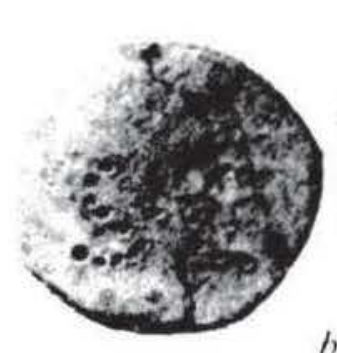

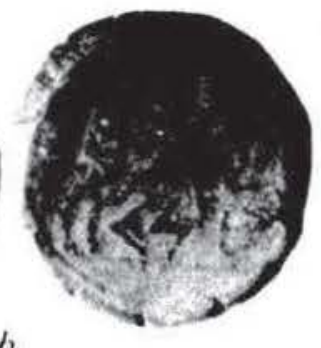

Figura 10.-Monedas y contramarcas mineras: a cuadrante de llipa ( 6 ): $h$ moneda de hese contramarcada con S(octetas)

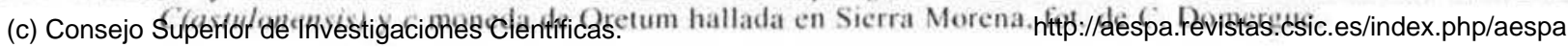
Licencia Creative Commons Attribution (CC-by) España 3.0 
cuando éste escasea lo retienen ilegalizándolo por medio de contramarcas privadas, lo "falsifican" con copias de monedas de Cástulo -las «Barbarisierungen» del Limes germánico-, téseras de plomo, o lo parten para disponer de numerario ${ }^{29}$. Más aún, se acaban de publicar unos lingotitos de cobre de unos dos centímetros de longitud con los pesos de ases, semises y cuadrantes procedentes en su mayoria de Linares (Cástulo), que vinieron sin duda a substituir la moneda cuando ésta escaseaba ${ }^{30}$. Estas téseras o esas monedas contramarcadas, con valor adquisitivo exclusivamente en el territorio económico cerrado que las emite, permiten detectar esas sociedades cerradas, cuya población se caracteriza además por una gran mezcla étnica: celtíberos, cántabros, galaicos, galos o norte-africanos creando ambientes culturales muy sincréticos y extraños al resto de la población. Incluso los cultos religiosos en estos territorios son diferentes a los que conocemos en las zonas urbanas más próximas. Es el caso del culto a Vulcano, inexistente en los ámbitos ciudadanos, del que Brommer escribía «... dass wir Mühe haben, in Spanien überhaupt eine Darstellung oder Erwähnung des Gottes zu finden.», afirmación que confirmaba A. Blanco años después; y sin embargo, se constata un denso culto a través de la iconografia monetal en las zonas mineras. Téseras monetales y monedas con la efigie de Vulcano (fig. $10 \mathrm{a}$ ), procedentes de zonas mineras del valle del Guadalquivir, indicando que sólo en esos ambientes existía el culto al que Ciceron -de nat. Deorum 1,84- se refiere como similar al de Vulcano pero con nombre diferente, posiblemente un culto prerromano anquilosado, habiendo trascendido su rara denominación a las elites romanas de la República ${ }^{3 !}$.

\section{Area territorial de culto}

La moneda es un documento esencial para determinar cuál es la evolución del culto estatal de las

\footnotetext{
${ }^{24}$ El fenómeno de la copia en ámbitos carentes de suficiente numerario está bien atestiguado en todo el Limes germánico y en España en las minas, $c f$. F. Chaves, "La circulación monetaria en las cuencas mineras de Riotinto y Cástulon, Habis 18-19. 1987-1988, pp. 613-637.

${ }^{30}$ Existen incluso lingotes forrados, de alma de plomo y foro de cobre, aunténticas falsificaciones «monetales», J. Roer Riera, "¿Pequeños lingotes de bronce utilizados como «monedas mineras»?, Gaceta Numismática 112, 1994, pp. 7-11. He podido conocer más ejemplares gracias al Sr. Gabaldón (Badajoz).

${ }^{31}$ F. Brommer, "Vulcanus in Spanien", MM 1971, pp. 147152; A. Blanco, "Ein Kopf des Vulkans in Cordoba", ibm 1975, pp. 263-266: M. P. García-Bellido, "Sobre el culto de Volcanus y Sucellus en Hispania: testimonios numismáticos", en J. Arce \& F.Burkhalter, Bronces y Religión romana, Actas del XI Congreso Internacional de Bronces Romanos, CSIC, Roma 1993, pp. 161-170.
}

ciudades que acuñan y cuáles las interpretationes que éste sufre. Para estudios de religiosidad urbana contamos con fuentes arqueológicas y literarias, reiterativas muchas veces en estos aspectos. Pero existe otro tipo de cultos de raices preurbanas, más dificiles de delimitar, que incluyen normalmente territorios amplios y en general fronterizos. Me refiero a santuarios rurales que han podido jugar un papel socio-económico importante, situados muchas veces en un cruce de caminos, del que dependen cultualmente pueblos varios. Para España se conocen mál, pero tanto en el mundo fenicio como helénico o itálico hay buenos ejemplos de la función de estos enclaves y de su importancia y pervivencia en época romana ${ }^{32}$. La Numismática podría revelarse como un documento esencial para delimitar este tipo de territorios si pudieramos comprobar que esos "grupos tipológicos» o "zonas de influencia», tenidos como conjuntos de ciudades secundarias que copian la imagen monetal de la urbe más importante, son en realidad testimonio de un culto común que, con ciertas jerarquías o sin ellas, afecta a los núcleos urbanos asentados en ese territorio. El más claro, por los abundantes datos literarios que poseemos sobre él, es el del santuario-mercado gaditano, interpretado desde hace mucho como el centro económico de ciudades cercanas a Gades, inmersas en un mismo circuito cultual y económico demarcado por ciudades que emiten con imágenes de Hércules. Todo ello ha obligado a plantearse si Gades no capitalizaba un territorio cultual mayor que el comprendido en las Gadeira ${ }^{33}$. La representación en monedas de objetos sacros, los altares gaditanos en las monedas de Lascuta por ejemplo, podría indicar una relación más intima entre éstas y aquél, la existencia de auténticas anfictionías o dependencias. Sabemos por el bronce de Paulo Emilio que los lascutanos eran Hastiensium servei, cuya ciudad era el lugar de re-

\footnotetext{
${ }^{32}$ Es el caso de Kition donde el templo de Astarté jugaba un papel económico trascendente. F. Coarelli, I Santuari del Lazio in etá republicana, Roma 1987; M. Torelli, Guida archeologiche Laterza: Etruria. Roma s/a, "Lucus Feroniae», pp. 30-35.

${ }^{33}$ M. E. Aubet, Tiro y las colonias fenicias de occidente, Barcelona 1987, pp. 239-243; M. P. Garcia-Bellido, "Leyendas e imágenes púnicas en las monedas libio-fenicias», Veleia 2-3, 198 p. 518: L. Mafredi, «Melqart e il tonno" SEAP I (1987) p. 67: ead. "Le saline e il sale nel mondo punico, «RSF 1, 1992, pp. 6-14: L. Garcia Moreno, "Ciudades béticas de estirpe púnica", Dialoghi di Archeologia 1992, p. 123; un estudio muy específico y bien documentado para delimitar el circuito, donde las monedas han jugado un papel importante en $F$. Chaves \& E Garcia Vargas, "Reflexiones en torno al área comercial de Gades...» Gerion 1991, pp. 139-168. No creo que deban incluirse las monedas con sólo delfines y menos con sábalos, peces de rio.
} 

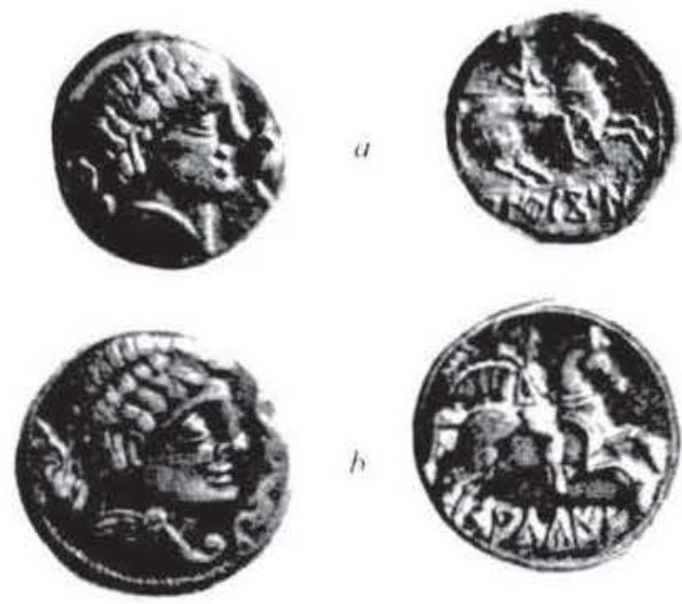

h
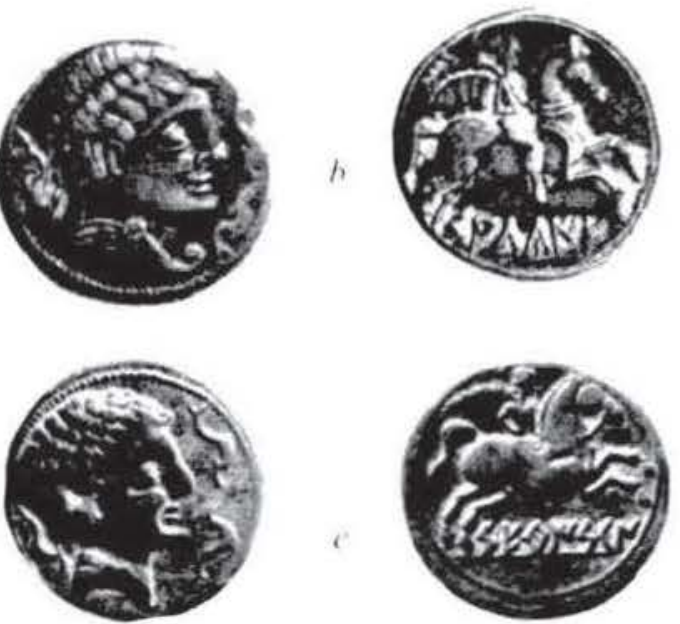

Figura 11. Monedas del valle del Ebro: a Contrebia belaisca h Salduic y e Seteisken, (ol IVDJ

unión de los gaditanos según Estrabón (3.2.2), constituyendo los tres enclaves un triángulo de intimas relaciones politicas que las monedas dejan muy claro ${ }^{4}$.

Es muy posible que también el grupo ibericoceltibérico "de los dos o tres delfines» responda a un culto común, cuya divinidad masculina fluvial es representada en las monedas de todo un territorio que monta sobre ambas márgenes del rio Ebro, zona fronteriza entre iberos, celtiberos, vascones y berones (fig. 11). El tema esta por estudiar.

4 He planteado en elas cecas libio-feniciasn cit. (n. 3). pp. 104-105 y 125 que Hasta (Regia) sea el topónimo formado a partir del lugar de reunión de los gaditanos (Fstraben). «tribunal de los centumvirim. lugar denominado en latin Hasta como vió ya Mommsen. (RE s/v. col. 2502: Suet. Aug. 36, «centumverialem hastamm, etc.). Esta interpretación justificaria su clara ortografia con $\mathrm{H}$ en Plinio 3.11 y sobre todo en el mismo bronce lascutano, Hastiensium servei. Es posible que el nombre latino no sea sino una traducción del topónimo púnico $\mathrm{B}^{\top} \mathrm{L}$ - consejo. asamblea - que aparece en unas monedas. de tipologia exacta a las de Gades, y que resulta ser el mismo que encontramos en las de Bula Regia - B'L. Que hasta llegase a convertirse en un topónimo tendria paralelos en los casos en que Foro o Curia sufrieron la misma trasformación. Fsta concepción latina de topónimo ha dado en español la palabra subasta=sub-hasfa. lugar donde se celebraban las ventas públicas amparadas por los centumviri. Esta interpretación podría suponet que los lascutanos

\section{luem Feroniac}

Un ejemplo mejor documentado que pudiera servir, por el ámbito claramente fronterizo que ocupa. de paradigma para detectar el territorio cultual de un santuario extra-urbano, es el de esa diosa femenina galeada con armas, espigas, peces y astros. efigiada en epoca republicana en muchas monedas de la Betica oceidental y de Lusitana (fig. $12 a, b, c$ y d). y denominada salus y Bellona en epoca imperial. cuyo eufo vamos a poder perseguir, aunque sea a retazos, a través de toda la dominación romana del territorio. pero cuyas raices han de ser sin duda muy anteriores; comencemos por los testimonios mas tardios.

La divinidad debió tener su santuario en el Trampal (Alcucscar), en un cruce de caminos que franqueaba la frontera formada por los montes de San Pedro. Montanche\%, Giuadalupe y EI Pedroso, cadena que deslinda la cuenca del Guadiana y la del Tajo y con ello posiblemente a vettones, lusitanos y Celtici. Documento posiblemente tardio de ese culto son las diecisicte lápidas, siempre aniconicas, dedicadas a Ataecina y hoy descubiertas por L. Caballero como material reutilizado en la iglesita visigoda de El Trampal "5. Las condiciones económicas - riqueza ganadera, agricola y sobre todo de mineral de hierro y topográficas - monte con arboleda y vegetación frondosisima, más los numerosos manantialeshacen sospechar al excavador que el lugar de El Trampal fue un enclave apropiado para un santuario primitivo que no tuvo por que conllevar edificios templarios pero si un témenos donde se depositarian los exvotos a Ataecina. entre ellos las numerosas aras votivas encontradas alli. Utilizando estos datos de L. Caballero he propuesto en un reciente articulo el que este santuario sea el descrito por las fuentes literarias como perteneciente al territorio emeritense y denominado por los agrimensores tardios como el lucus Feroniae, exento de centuariación por

fucran siervos thastiensium, de los centunviri y no de una comunidad politica llamada Hasta, lo cual abriria una nueva discusion en el tema.

Un estudio completo de M. Abascal en este mismo volumen Información anterior en L. Caballero y J. Rosco. Primera campaña de trabaios arqueológicos, 1983-1984, Extremadura Arqueolo. gica I. 1988, pp. 231-249: idem. Iglesia visigoda de Santa Maria del Trampal. Alcuéscar (Caceres) Informe preliminar. Segunda campaña de excavaciones arqueológicas, en prensa. Yo debo y agradezco a L. Caballero toda la información aqui vertida y ya publicada en parte por mi ( «Las religiones orientales en el peninsula ibérica: testimonios numismáticosm, AEspA 1991, pp, 60-75). no sólo de todos los materiales arqueológicos, sino también de su corpus de inscripciones sobre el culto a Alaccina, comentarios orales, etc. 

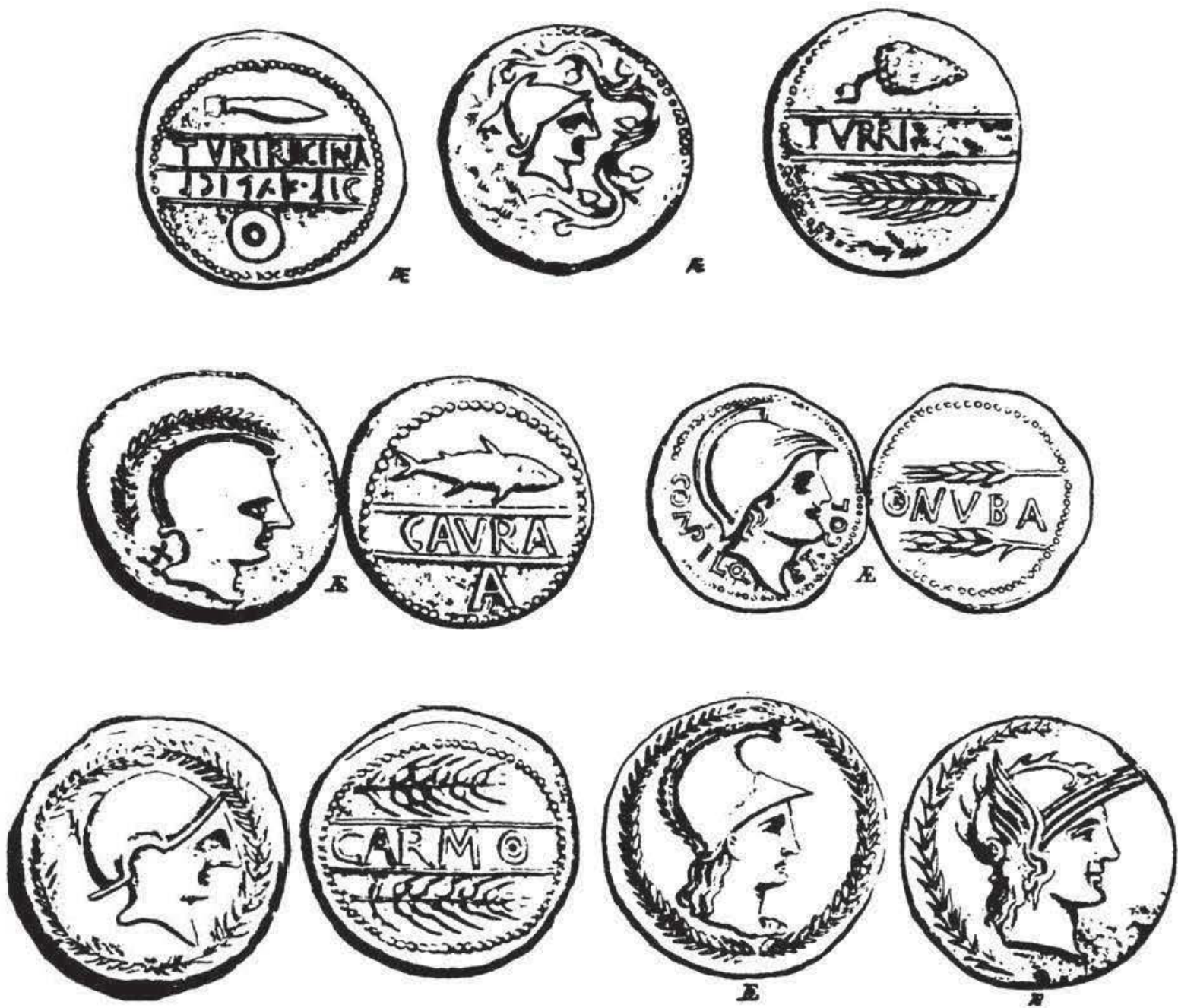

Figura 12.-Algunas monedas béticas con imágenes de divinidades femeninas galeadas, armas, espigas y peces. Dibujos de A. Heiss.

constituir silva publica, y de una extensión de 1.000 yugadas, $2.500 \mathrm{~m}^{2} .{ }^{36}$ Es indudable que la denominación de Feronia se debe a la interpretatio Romana de una divinidad indigena que ha de ser la hoy atestiguada allí gracias a la epigrafía, Ataecina. Esta interpretatio nos va a proporcionar mucha información para determinar la esencia de la divinidad del Trampal.

Feronia es una divinidad posiblemente sabina en cuyos dos santuarios más importantes, Capena y Tarracina, poseía un lucus propio sito en Capena

${ }^{36}$ Agennius Urbicus, de controversiis 37,13; Hyginius, de limitibus, 135,15 y 136. La arqueología atestigua la carencia de habitación romana én esa zona: E. Cerillo y J. M. Fernández, "Contribución al estudio del asentamiento romano en Extremadura. Análisis espacial aplicado al S. de Trujillo, Norba I, 1980, pp. 157-175. Cf. comentario más detallado en M. Abascal en este mismo volumen. sobre el cruce de cáminos entre etruscos, sabinos y latinos. Su prerrogativa principal era la protección de las aguas y con ello su esencia de dispensadora de la salud, atribuciones bien constatadas en las fuentes literarias donde se la denomina uninfa de Campania» (Ser., Aen. VIII, 564 ) o se la describe como Feronia Terracinae viviendo bajo el lacus. (Vibio en Seq.p. 153,10) y poseyendo un collegium aquattorum Feroniensium en Aquileia. Pero además, como portadora de agua, era protectora de la producción agropecuaria, especialmente del grano como muestran dos basas dedicadas a la diosa en su témenos de Capena calificándola de salus y frugifera ${ }^{37}$. Sin duda son los exvotos hallados en las excavaciones en Tarracina, miembros humanos y animales,

${ }^{37}$ M. Torelli, cit. (n. 32) p. 33; cf. además mi artículo cit. (n. 35), pp. 69-75. 

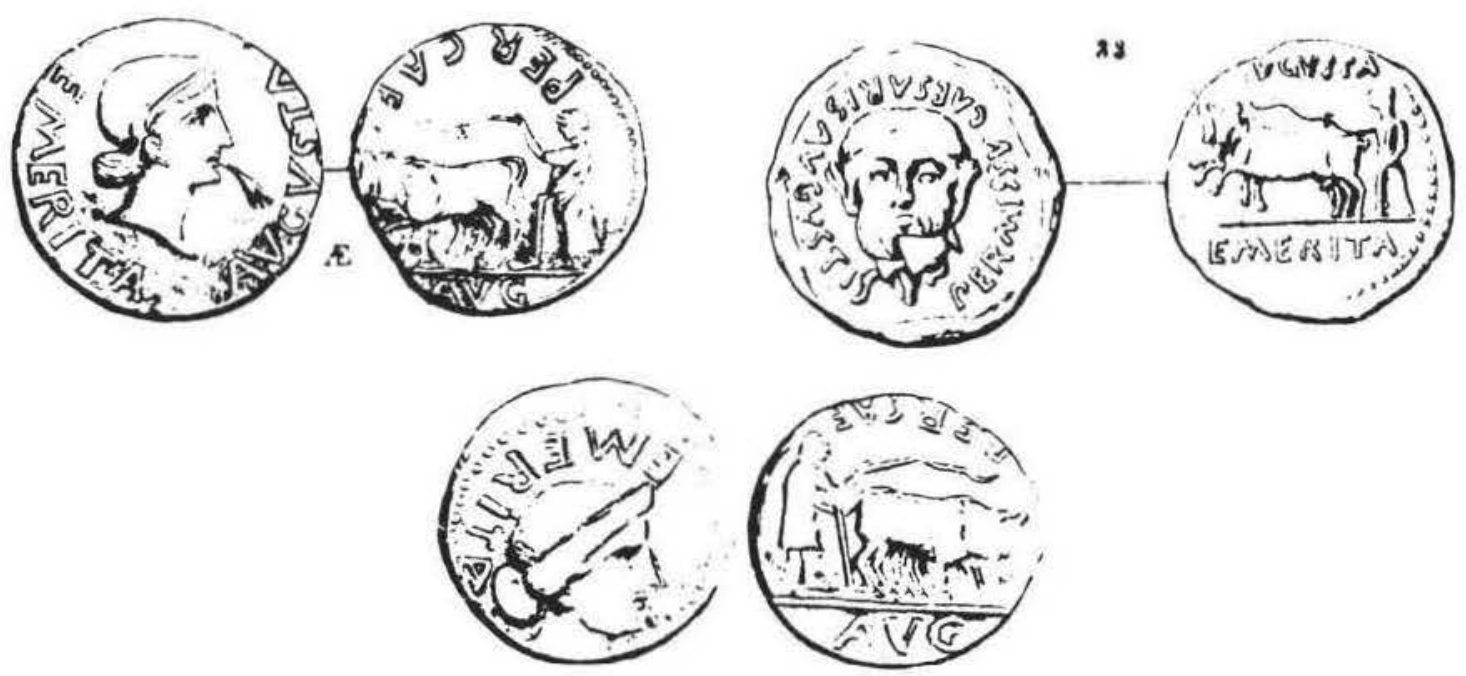

Figura 13,- Ases de Emerita: $a$ ¿representación de Ataecina como ninfa emeritense?: $b$ ¿representación de El Guadiana?: c Ataecina filostéfanos. Dibujos de Heiss.

los testimonios arqueológicos de esos textos epigráficos y literarios comentados. Además, y constituyendo quizás su sentido primigenio, era una divinidad infernal y del bosque: dea agrorum sive inferorum. ${ }^{3 .}$ características que se convierten en epitetos en boca de Dionisio de Halicarnaso (Ant III 332,1):

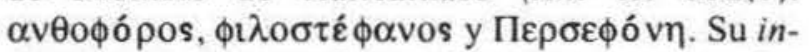
terpretatio con Persefone es la misma que la confirmada en Emerita: Ataecina/ Proserpina-CIL II, 462.

El culto a Ataecina se extendió por todo el territorio emeritense y más allá, homologándose textualmente la divinidad con Proserpina tan sólo en la propia Emerita en los dos conocidos epígrafes uno de ellos encontrado precisamente en el pantano de la colonia, relacionando a la diosa con las aguas al igual que la erección de su santuario en un lugar lleno de manantiales como El Trampal ${ }^{39}$. Es interesante constatar que la homologación de las dos divinidades - Proserpina=Ataecina- se hace sólo alli donde la romanización había arraigado más, aun cuando en ambas inscripciones se citen los nombres de ambas, indicando que no se ha hecho una auténtica hypostasis. Sin embargo, en las treinta y dos lápidas restantes dedicadas a Ataecina y recogidas por L. Caballero y publicadas por J. M. Abas-

* Corp. gloss. Lat. V 456, 23; 500,47. Su esencia infernal es aceptada por G. Radke, Die Götter Altitaliens, Münster 1965. pp. 124-127 y por A. Prosdocimi, "Le religione degli italici», en C. Ampolo et alii. Italia, Milan 1989, p. 534.

${ }^{39}$ Más exvotos en agua dedicados a Ataecina son los aparecidos en el arroyo de Torrejoncillo y en el Guadiana (datos de L. Caballero), cf. cit. (n. 35) p.71. cal en este mismo vólumen no existe ninguna otra traducción.

Las monedas podrían mostrar que el culto a Ataecina en el territorio emeritense es muy anterior al establecimiento de la colonia, y que ésta no vino sino a romanizar a una divinidad bien arraigada en aquél, llamándola Proserpina en la capital de la provincia, Feronia en su lucus, y posiblemente Tanit en las ciudades púnicas de la Beturia túrdula, región a la que según Estrabón $(3,2,15)$ pertenecia Emerita.

Las monedas augusteo-tiberianas de la propia Emerita son los mejores testimonios del proceso de aculturación que Ataecina sufre. Como ninfa de Emerita y patrona de la ciudad la vemos en los bronces que hacen alusión a la fundación de la colonia, representando en reverso la yunta fundacional (fig. 13 a). Es indudable que la imagen del anverso con la leyenda EMERITA AVGVSTA a su derredor ha de ser la divinidad principal que representa la ciudad, la «ninfa emeritense», hija del río Guadiana, el Aqueloo de cuya sangre nacen las ninfas, que aparece efigiado en la emisión paralela (fig. 13 b). Pero además, Emerita efigia una cabeza femenina diademeda, única en las acuñaciones hispanas que podría hacer referencia al epiteto de Dionisio de Halicarnaso citado: filostéfanos, amante de las diademas (fig. $13 \mathrm{c})^{40}$.

40 No me extiendo en el tema por ser tratado en más detalle en "Lucus Feroniae emeritense" en II Colóquio internacional de epigrafia: Divindades indigenas e interpretatio Romana, Cintra, Marzo 1995, en prensa. 


\section{IA IMAGIVDI IN IIRRIIORIC}

Un valor mas ideoleggeo, aunque en ültimo termono tambien geografico. poscen las imagenes monetales como emblemas de estado. Nadic duda que una de las formas mas plastica y efica/ de la propagandir politica afenense fueron sus tipos monetales, arcairantes y repetitisos. Es seguro que si algunosciudadanos del Alica lejos de su patria hubieran queride dejar constancia de su pedigree habrian acuíado con eson mismos tipos, indicando claramente que eran atentense's

Cuando la peninsula iberica se divide en dos provincias administratisa y fiscalmente diferentes, de facto con Caton. la citerior usa de una escritura común, la iberica. y unos tipos monetales uniformes. el jinete (fig. 14). Es seguro que muchos de los distintos pucblos que constituyen la citerior vaseos. pucblos del norte. berones, celtiberos. iberos, wibeross de Catalunia, etc. no tenian entre el repertorio de su iconografia una imagen semejante. ni un contenido mitologico que cuadrase bien con esa imagen monetal que se consertia de repente en su emblema etnico. Pero pasado un largo historial de rebeliones contra Roma en la que muchas veces estos distuntos pueblos se stumaron para defenderse, la unidad de escritura y de imagen monetal acabó conviertiendose en el simbolo de unidad politica entre ellos, y su mejor prucba es que Sertorio elija ese tipo y esa escritura para sus masivas acuñaciones rebeldes. Terminada la guerra con Sertorio se provoca, sin duda desde las nuevas altas esferas ciudadanas, una latinizacion acelerada de los epigrafes. desterrando la escritura iberica de las monedas, y una desmitificacion del territorio común suprimiendo el jinete y eligiendo tipos ciudadanos diversos como coronas civicas, magistraturas cuyo titulo ocupa

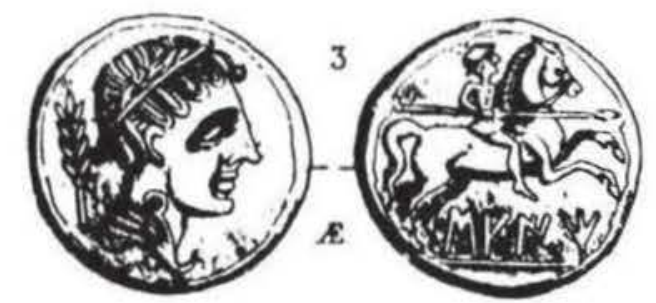

Figura I4 As republicano de Saiti. Dibajo de A. Ileiss.

"No haré aqui sino esbozat el tema pues lo trato con más detalle en "La imagen de Hispana y su prehistoria", en R. Olmos y J. Santos (edits.). Actas del Coloquio sobre leonogratia therica e iconografia italica: propuestas de interpretacion y de lectura. Roma 1993, CSIC en prensa. el tipe monetal allVIRI" (fig 15). dis midades poliadas, etc. etc $\$ 1$ jincte iberico. cmblema de la cifertor. aciba por desaparecer sustituido, como digo. por otros tipos con otras ideologias. Pero es indudable que su keono habia llegado a convertirse en la imagen de un territorio, tanto para los implicados como para los ajenos.

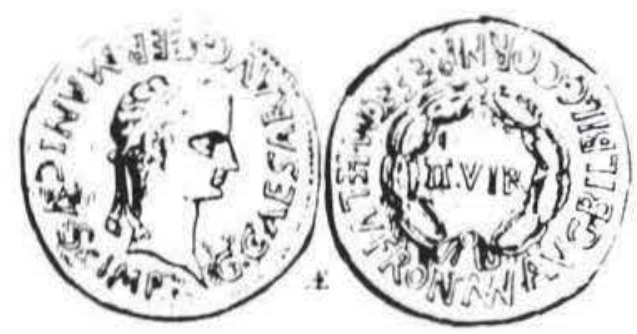

Figura 15 As de Catigula emitido en Bithilis. Dibuio de Hews

\section{Las actuiaciones Hispanorum}

Sabemos por Livio que la ciudad de Morgantina fue entregada a mercenarios hispanos tras su destruccion por los romanos en el -212 como premio a su comportamiento en el sitio y entrega de Siracusa. tras un pacto con Mercellus de uno de los jefes hispanos, Moericus, a quién se le gratifico con el honorable estatus de ciudadano romano primer caso constatado en nuestra historia - mas 500 yugadas de tierra. Pero poco mas sabiamos sobre Morgantina hasta las excavaciones llevadas a cabo por la universidad de Princeton en Serra Orlando, en las que la abundancia de monedas con leyenda MOPTANTIN $2 \mathrm{~N}$ y sobre todo HISPANORUM, ha permitido identificar el yacimiento con la Murgentia protagonista de nuestra historia y ceca de las monedas que nos ocupan (fig. 16). Fistas monedas Hispanorum se conocian de antiguo y se habian asociado con Sicilia, sin mayor precision, por la mayoritaria presencia en la isla y su. en cambio llamativa, ausencia del territorio hispánico: pero en cuanto a su
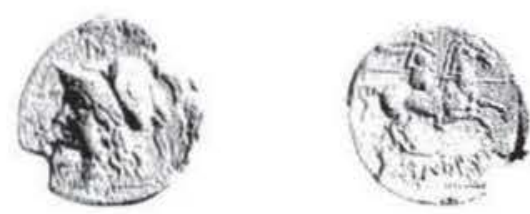

Figura 16. Moneda de bronce emitida en Morgantina con étnico Hispanorum. Col. IVDJ. 
ceca y cronologia se relacionaban con la presencia en la isla de Sexto Pompeyo y sus conexiones hispanas tras su larga estancia en la Peninsula. Las excavaciones de Serra Orlando han aconsejado sin embargo dar a estas monedas unas fechas muy anteriores a Pompeyo, posiblemente acuñadas desde los comedios del siglo $\|$ al primer cuarto del siglo । $y$, como hemos visto, una patria precisa ${ }^{+2}$. Estas nuevas coordenadas de tiempo y espacio obligan a una nueva interpretación del étnico Hispanorum que ahora Erim ha sugerido tenga que ver con los herederos de aquéllos mercenarios a quienes se les donó la ciudad como premio por la entrega de Siracusa a los romanos. Las monedas serian pués acuñaciones de una segunda generación en la que, no sólo se mantendría viva la noticia del origen étnico de sus antepasados, sino que quisieron ellos convertirlo en mito fundacional haciéndolo constar en el objeto más emblemático de la ciudad, la moneda con la leyenda HISPANORUM ${ }^{43}$. Pero a mi juicio el tema no acaba ahi, pues, aunque el tipo del jinete elegido para alguna de estas emisiones se puso pronto en relación con el de la moneda ibérica, se justificó en la genérica habilidad de los hispanos que habria sugerido tanto el tipo originario ibérico, como el elegido ahora por los Hispani de Morgantina, descartando sin embargo explicitamente la posible conexión directa, de copia, entre las acuñaciones pe-

4: La cronologia más alta. fines del siglo 111 , propuesta por M. Caccamo Caltabiano ( $\propto$ Sulla cronologia e la metrologia delle serie Hispanorumm. OT 14. 1985. pp. 159-169). me parece poco probable por los hallazgos en los mismos estratos de monedas ibéricas del jinete, y por ser los ases de untikesken el modelo exacto de algunos tipos Hispanorum, ef $\mathrm{mi}$ art. cit. en nota anterior.

"K. Erim, "Morgantina" A.JA 67. 1958, pp. 79-90; Id. "Coins of the second and first Century B. C.: the Hispanorum seriess. en Th. Buttrey et alii. Morgantina Studies, vol II. The Coins. Princeton 1989. pp. 34-68: A. Garcia y Bellido, "Moericus, Belligenus y los mercenarios españoles en Siracusan. BRAH, 150. 1962. pp. 7-23. ninsulares y sicilianas. El asunto es mucho mas complejo pues no es sólo uno de los tipos de las monedas de Morgantina el que coincide con asunto hispánico, sino que también el dq "Atenea» es una copia fidedigna de las monedas de los iberos de untikesken (fig. 17). aunque efectivamente el del jinete sea

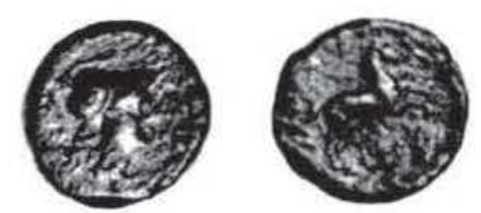

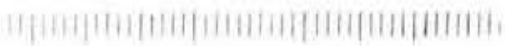

Figura 17. Divisot de bronce withesken (Ampurias) (iol. IVD)

el más importante por abundacia, continuidad y valor. Es indudable que la elección esta hecha con la voluntad de representar la imagen de un territorio. origen de ellos mismos, como Grecia lo era de sus convecinos, los Morgantini. Ahora, ¿por qué esos distintos tipos? ¿Qué imagen tenian ellos mismos del territorio hispano? ¿Quisieron con esa diversidad de tipos marcar los distintos puntos de origen de sus antepasados, o era la imagen plural de unos Hispani también plurales? ¿Eran conscientes todavia, en una segunda y tercera generación y a causa de sus bien diferentes lenguas, de que tras esta denominación romana de Hispani existian iberos, celtiberos y turdetanos? ¿Se habia perdido ya el étnico de iberos para los habitantes de Iberia que indudablemente hubo de ser el usado todavia entre los si. culos y griegos de Sicilia, sus conciudadanos, de quienes sin embargo copiaron ese genitivo plural? o ¿eligieron la escritura y el término latinos como elite, precisamente para diferenciarse del resto de los habitantes de la ciudad donde imperaba la terminologia griega? ¿Era esa su imagen del territorio hispano? 